
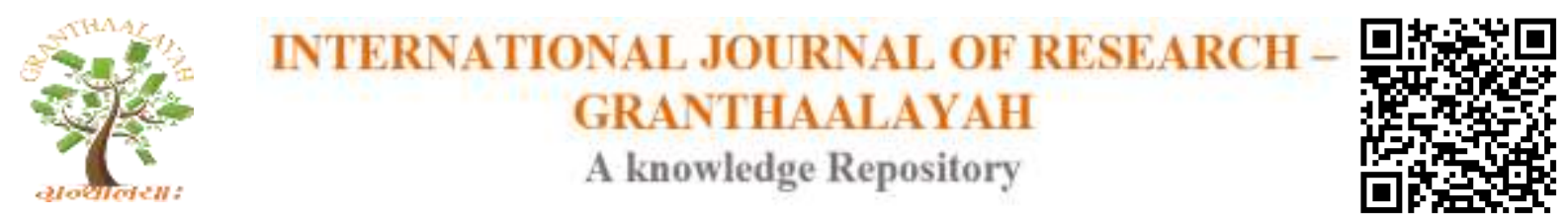

Social

\title{
EFFECTIVENESS OF ADVANCE ORGANIZER MODEL OVER CONVENTIONAL METHODS OF TEACHING OF SCIENCE AT SECONDARY LEVEL
}

\author{
Dr. Umesh Chandra Kapri ${ }^{* 1}$ \\ ${ }^{* 1}$ Associate Professor, Gold Field College of Education Faridabad, India
}

\begin{abstract}
An advance organizer is a very useful tool for teachers to help students in the classroom to understand, retain and remember new learning material. It is a tool used to introduce the lesson topic and illustrate the relationship between what the students are about to learn and the information they have already learned. The most general ideas of a subject are presented first and then progressively differentiated in terms of detail and specificity. Instructional materials are used to integrate new material with previously presented information through comparisons and cross-referencing of new and old ideas. An experimental study was conducted to know the effectiveness of Advance Organizer Model over traditional methods of teaching of science. The findings of the study show that there is significance difference between pre-test and post -test achievement scores of science. Thus, it is concluded that Advance Organizer Model is better in teaching of concepts of science than the conventional methods of teaching of science.
\end{abstract}

Keywords: Advance Organizer Model; Conventional Method; Achievement; Science.

Cite This Article: Dr. Umesh Chandra Kapri. (2017). "EFFECTIVENESS OF ADVANCE ORGANIZER MODEL OVER CONVENTIONAL METHODS OF TEACHING OF SCIENCE AT SECONDARY LEVEL." International Journal of Research - Granthaalayah, 5(7), 193-198. https://doi.org/10.29121/granthaalayah.v5.i7.2017.2121.

\section{Introduction}

Teaching- Learning situation is the main component in the field of education. Teaching is not up to the mark without the wide knowledge of teaching methodologies. It is necessary for a teacher to keep pace and compete with world. The methods which are used by a teacher if not appropriate cannot be effective teaching. Teacher must know individual differences and should set a link between teaching learning process for personality and cognitive development of an individual. One of the major problems in the field of education is low level of cognition. Educational Technology has been proved to be a boon and given a specific place in the national policy of Education 1986. Knowledge of instructional strategies corresponding to psychology of human learning is one of the major considerations of Educational Technology. Models of teaching which are based on human psychology are a component of Educational Technology. 
Researches like Carl Roger, Erik Erikson, Abraham Maslow, B.F. Skinner, Ausubel, J.S. Bruner, Jean Piaget, John Dewey etc. developed theories of learning. In other words various models of teaching were developed by these educationists and researchers for effective classroom teaching. Joys and well (1972) were the first to select the models out of the large numbers of models put forth by Psychologists, sociologists, system analysts, educators and others. They discarded those models which were too vague to provide general models that could be communicated to concern people working in the field of education. The researcher has selected the present topic as he wants to see the difference between traditional ways of teaching and output of Advance Organizer Model when it is used in the field of science.

\section{Advance Organizer Model}

An 'advance organizer is a cognitive instructional strategy used to promote the learning and retention of new information. Advance Organizer Model is given by David Ausubel who is one of the educational psychologists. This theory of meaningful verbal learning deals with three concerns:-

1) How knowledge is organized

2) How the mind works to process new information and

3) How teacher can apply these ideas about curriculum and learning when they present new material to students. This model is designed to strengthen student's cognitive structure.

Ausubel believed that learning proceeds in a top-down, or deductive manner. His theory consists of three phases, presentation of an advance organizer, presentation of learning task or material, and strengthening the cognitive organization. In this model teacher plays the role of organizer of subject matter and presents information through lectures, readings and providing tasks to the learner to integrate what has been learned. In this approach, teacher is responsible for organizing and presenting what is to be learned. The learner's primary role is to master ideas and information. The Advance Organizers provide concepts and principles to the students directly. The teacher retains control of the intellectual structure, to relate the learning material to the organizers and to help students differentiate new material from previously leads to the successful acquisition of material.

\section{Need and Significance of the Study}

The main aim of education is to bring all- round development in a child which is not possible with traditional methods of teaching. The teacher adopts conventional methods of teaching because either they do not have knowledge of innovative and modern methods of teaching or they are afraid of adopting new innovative and effective methods of teaching. The Advance Organizer Model given by Ausubel is one of them. He has focused on meaningful learning which is not possible by conventional methods. The model helps in overall development of children and provides better way of retaining knowledge useful means of applying them in their daily life situation and above all it helps in making better citizen of our country who will have a broad and clear vision and will have scientific attitude towards life. Panda (1986), Rajoria (1987), Senapathi Sanjuka (1986), Noon Kil (1982), Pachauri, D. (2007) have pointed out the effectiveness and usefulness of this Advance organizer model. In order to occur the meaningful learning and harmonious development among learners the researcher has selected the present topic as he wanted to see the difference between traditional ways of teaching and output of Advance Organizer Model when it is used in the field of science. 


\section{Objectives of the Study}

1) To study the achievement of IX standard students in Science.

2) To study the achievement of IX standard students in Science when they were taught by conventional method of teaching.

3) To study the effects of Advance Organizer Model on the achievement in Science of class IX students.

4) To construct the Instructional material for class IX students for Science teaching by Advance Organizer Model and conventional method.

5) To compare the achievement in Science of class IX students while using Advance Organizer Model and traditional teaching methods.

\section{Hypothesis}

There exists no significant difference between achievement in Science of class IX students while using Advance Organizer Model and Conventional Method of teaching.

\section{Population and Sample}

The sample consisted of 76 students studying in IX class in secondary schools located at Faridabad district of Haryana state. The school was selected by purposive sampling technique and the students were selected by cluster sampling technique. The sample was divided into two groups as per the strength of each section of class IX in a school. Group (A) consisted of 36 students taken as experimental group which was taught through Advance Organizer Model and Group (B) consisted of 40 students named as controlled group was taught through conventional Methods.

\section{Tools Used}

For the purpose of data collection the researcher constructed two achievement tests (Pre and Posttest) from the selected four topics of science. Pre-test was conducted to know the depth knowledge of students about science. Post- test was based on the content material of selected four topics of science taught.

\section{Procedure of Data Collection}

In the present study experimental design was used. First achievement test (Pre-test) was administrated to class IX students to know their achievement in science before treatment. Then both the group was taught selected four topics of science taught for a period of three months. One of them known as controlled group was taught by the conventional method of teaching and the second group known as experimental group was taught by using Advance Organizer Model. After the treatment of three months an achievement test in science from the selected four topics was constructed and administered on the sample of both the groups. The scores obtained by each student of both controlled group and experimental group were analysed and interpreted by using descriptive and inferential statistics. 


\section{Delimitations of Study}

The study was delimited in the following aspects.

1) The study was confined to 100 students of class IX.

2) The study was further restricted to four selected concepts of Science.

3) The present study was conducted on IX class students of secondary schools located at Faridabad district of Haryana.

\section{Analysis and Interpretation}

The sample was consisted of two groups. Group (A) consisted of 36 students taken as experimental group which was taught through Advance Organizer Model and Group (B) consisted of 40 students named as controlled group was taught through conventional Methods.

\section{Comparison of pre-test Achievement Scores of Science between Control and Experimental Group:}

Table 1: Shows descriptive statistics of achievement scores of science of pre-test.

\begin{tabular}{|l|l|l|l|l|l|l|l|l|l|}
\hline Table -1: Achievement Test (Pre-test) \\
\hline Groups & $\mathbf{N}$ & $\begin{array}{l}\text { Minim } \\
\text { um }\end{array}$ & $\begin{array}{l}\text { Maxi } \\
\text { mum }\end{array}$ & Sum & Mean & $\begin{array}{l}\text { Std. } \\
\text { Error }\end{array}$ & $\begin{array}{l}\text { Std. } \\
\text { Deviation }\end{array}$ & t-ratio & Remarks \\
\hline Control & 40 & 16 & 38 & 1189 & 29.72 & .982 & 6.21 & 0.94 & Insignificant \\
\hline Experimental & 36 & 19 & 39 & 1119 & 31.08 & 1.07 & 6.37 & 0.94 \\
\hline
\end{tabular}

No significant difference was found between control and the experimental groups at pre-test achievement scores of science as calculated ratio was found to be 0.94 which is not significant at 0.01 and 0.05 levels of significance. Thus, it can be concluded that there is no significance difference of achievement scores in science between Control and Experimental Group. The result shows homogeneity of the sample.

Comparison of post-test Achievement Scores of Science between Control and Experimental Group:

Table 2: Shows descriptive statistics of post -test achievement scores of science.

\begin{tabular}{|c|c|c|c|c|c|c|c|c|c|}
\hline \multicolumn{10}{|c|}{ Table -2:Achievement Test (Post-test) } \\
\hline Groups & $\mathbf{N}$ & $\begin{array}{l}\text { Minim } \\
\text { um }\end{array}$ & $\begin{array}{l}\text { Maxi } \\
\text { mum }\end{array}$ & Sum & Mean & $\begin{array}{l}\text { Std. } \\
\text { Error }\end{array}$ & $\begin{array}{l}\text { Std. } \\
\text { Deviation }\end{array}$ & t-ratio & Remarks \\
\hline Control & 40 & 19 & 41 & 1309 & 32.72 & .971 & 6.20 & \multirow{2}{*}{5.78} & \multirow{2}{*}{ Significant } \\
\hline Experimental & 36 & 29 & 49 & 1479 & 41.08 & 1.16 & 6.39 & & \\
\hline
\end{tabular}

A significant difference was found between control and the experimental groups at post-test achievement scores of science as calculated t-ratio between control and the experimental groups at post-test was found to be 5.78 which is significant at 0.01 and 0.05 levels of significance. Thus, it can be concluded that there is significance difference of achievement scores in science between Control and Experimental Group at post-test. The result shows that Advance Organizer Model was better than the conventional Methods of teaching of science. 
Comparison between pre-test and post-test Achievement Scores of Science of Control Group:

Table 3: shows descriptive statistics of pre-test and post -test achievement scores of science of control group.

\begin{tabular}{|l|l|l|l|l|l|}
\hline Table -3:Achievement Test (Control group) \\
\hline Tests & N & Mean & $\begin{array}{l}\text { Std. } \\
\text { Deviation }\end{array}$ & t-ratio & Remarks \\
\hline Pre-test & 40 & 29.72 & 6.21 & 2.16 & Insignificant \\
\hline Post-test & 40 & 32.72 & 6.20 & & \\
\hline
\end{tabular}

No significant difference was found between pre-test and post-test achievement scores in science of control group as calculated ratio was found to be 2.16 which is not significant at 0.01 level of significance. Thus, it can be concluded conventional teaching method is not effective method of teaching science.

\section{Comparison between pre-test and post-test Achievement Scores of Science of Experimental Group:}

Table 4: shows descriptive statistics of pre-test and post -test achievement scores of science of Experimental group.

\begin{tabular}{|l|l|l|l|l|l|}
\hline \multicolumn{7}{|l|}{ Table -4:Achievement Test (Experimental Group) } \\
\hline Tests & N & Mean & $\begin{array}{l}\text { Std. } \\
\text { Deviation }\end{array}$ & t-ratio & Remarks \\
\hline Pre-test & 36 & 31.08 & 6.37 & 7.01 & Significant \\
\hline Post-test & 36 & 41.08 & 6.39 & & \\
\hline
\end{tabular}

A significant difference was found between pre-test and post-test achievement scores in science of experimental group as calculated ratio between pre-test and post-test achievement scores in science was found to be 7.01 which is significant at 0.01 and 0.05 levels of significance. Thus, it can be concluded that Advance Organizer Model was very effective for teaching of science.

\section{Major Findings of the Study}

1) The Teaching of Science by the Advance organizer Model is better than by the conventional methods of teaching of science.

2) Advance organizer Model of teaching appealed to the students very much and they felt encourage to learn the subject matter with interest which was present to experimental group during the experiment. The results of the experimental design prove the superiority of Advance organizer Model over the traditional method.

3) The mean achievement score of the experimental groups were highly significant than the mean score of the controlled group at post -test which could have not come by chance. It is statistical proof of the superiority of the experimental method.

4) Not only the mean scores were higher on the whole achievement test out they were significantly higher on the test items based on the material presented through the 
Advance organizer Model. This observation suggests that the traditional method presenting the subject matter to the students in hackneyed and require reorientation.

\section{Suggestions for Further Study}

The following suggestions may be suggested:

1) As the present study was confirmed to a small group, it is recommended that the experiment may be conduct on a large sample.

2) The experiment can be taken with pupils of different levels of intelligence at the different levels.

3) The experiment can be replicated for long period to see the impact of Advance organizer Model on cognition of the students.

4) Only one model was selected for the study, other models can also be studied.

\section{References}

[1] Ausubel, D. (1978). In defense of advance organizers: A reply to the critics. Review of Educational Research, 48, 251-257.

[2] Ausubel, D. P. (1960). The use of advance organizers in the learning and retention of meaningful verbal material. Journal of Educational Psychology, 51, 267-272.

[3] Buddhi sagar, Meena (1987), Development and comparision of instructional material developed by using advance organizer model and operant conditioning model for teaching to BEd. students, Devi Ahilya Vishwavidayala Indore.

[4] Joyce, B., \& Weil, M., \& Calhoun, E. (2003). Models of teaching (7th ed.). Englewood Cliffs, NJ: Prentice-Hall.

[5] Mayer, R. (2003) Learning and Instruction. New Jersey: Pearson Education, Inc.

[6] Ogle, D. S. (1986). K-W-L group instructional strategy. Teaching reading as thinking (Teleconference Resource Guide, pp. 11-17). Alexandria, VA: Association for Supervision and Curriculum Development.

[7] Pachauri, D. and Nand V.K (2007), Comparison of Advance organizer model and concept attainment model for teaching concept of science to standard IX, V.M.U. salem, Tamilnadu.

[8] Passi, B.K. and Awasthi, V.K.(1988), Developing Training strategy for science and teaching by using concept attainment. Ph.D thesis, model, Devi Ahilya viswavidyalaya Indore.

[9] Sansanwall D.N (1977), An experimental study in programmed learning for teaching research methodology course at MEd level Ph.D Unpublished dissertation M.S. university of Baroda.

[10] Stone, C. L. (1983). A meta-analysis of advanced organizer studies. Journal of Experimental Education, 51(7), 194-199.

*Corresponding author.

E-mail address: jjucktulsi@ gmail.com 